\title{
The genetics of colour polymorphism in the aposematic Jersey Tiger Moth Callimorpha quadripunctaria
}

Tony G. Liebert* and

Paul M. Brakefield $\dagger \ddagger$

\author{
* The Heathfield, Crowcombe Heathfield, Taunton, \\ U.K. \\ † Section of Evolutionary Biology, Department of \\ Population Biology, University of Leiden, \\ Schelpenkade 14a, 2313 ZT Leiden, The Netherlands.
}

The colour polymorphism in the warningly-coloured moth Callimorpha quadripunctaria (Lepidoptera: Arctiidae) involves three major phenotypes with bright red, orange or yellow hindwings. These are controlled by two unlinked gene loci, each with a pair of alleles exhibiting complete dominance. One locus, when homozygous recessive, is epistatic to the other. Allele frequencies in the polymorphic populations of the geographically peripheral and ecologically marginal region of southwest England are inferred from data on phenotype frequencies. These populations show high frequencies of each allele at the two loci with some evidence of clines within the region.

\section{INTRODUCTION}

Colour patterns of aposematic Lepidoptera and other insects which are protected by a chemical defence are usually uniform within populations. The Jersey Tiger Moth Callimorpha quadripunctaria is an exception since it is sometimes strikingly polymorphic (Brakefield and Liebert, 1985). Throughout most of its wide range this species has bright red hindwings but moths in the polymorphic populations may be red, yellow or orange. Such populations are only found in the extreme northwest of its distribution; in Brittany, the Channel Islands and southwest England. Why is there a striking visible polymorphism in a warninglycoloured species expected to converge on a single, effective warning signal; and why is the variation restricted to certain marginal populations? We report here on the mode of inheritance in C. quadripunctaria. The polymorphism is controlled by two unlinked loci with recessive epistasis; each gene locus having a pair of alleles. Knowledge of the genetics gives an insight into allele frequencies in the populations of southwest England.

\section{MATERIAL AND METHODS}

Stocks were established from female moths collected at various localities in south Devon over a

$\ddagger$ Author for reprint requests. number of years. Several pedigrees were set up including that illustrated in fig. 1. The scoring of wing colour is described by Brakefield and Liebert (1985). There are three discrete colour phenotypes which with experience and reference to specimens examined with a colour analyser can be unambiguously classified by eye. These major phenotypes are bright red, orange or deep yellow (illustrated in fig. 2 of Brakefield and Liebert, 1985). The orange colour appears to be due to a pure pigment and not to a mixture of red and yellow-coloured wing scales. There is some continuous variability within each of these three morphs. This is much more difficult to score and only the major phenotypes are considered here.

All families were reared by one of us (T.G.L.) near Taunton in Somerset. Ten or more males and females were placed together in a hanging net cage to obtain pairings. Cages prepared for different crosses were placed close to each other in a polythene tunnel to further simulate the apparent lekking behaviour observed in the field (Brakefield and Liebert, 1985). Moths were fed with a glucose solution. Matings occurred after dusk on warm evenings during late July and August. Individual pairings were removed between 22.30 and 23.30 to separate cages. Females were boxed the following morning prior to egg laying. Larvae hatched in about 16 days and were then reared in sleeved tubs containing growing foodplants; Pentaglottis sempervirens, Symphytum officinale, Lamium album, 

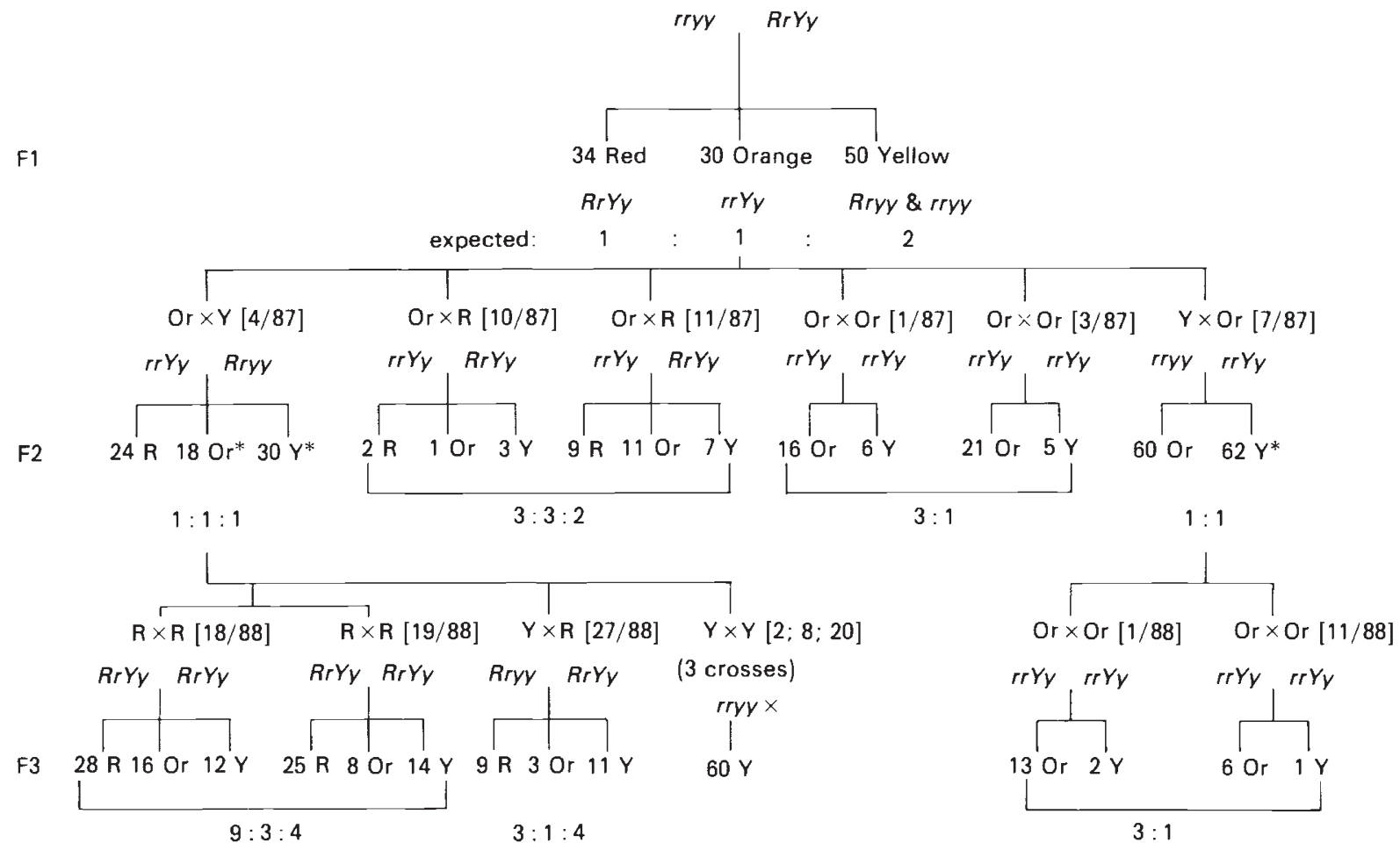

* Crosses of one of each of these moths to the pure breeding (J) Red line (RRYY) gave only red offspring as expected.

Figure 1 Pedigree for some of the families of Callimorpha quadripunctaria used to determine the genetics of the colour polymorphism. The colours and inferred genotypes of parents (female: male) of each family (codes in square brackets) are given together with offspring numbers and the expected segregation ratios.

Urtica dioca and Senecio squalidus. Plants were replaced as required. Dead, dry leaves of oak and beech were placed in the tubs used for overwintering of young larvae in an outbuilding. The tubs were placed outdoors in a sunny aspect in late spring and moss was added to them in June prior to pupation. Moths were then allowed to eclose within the tubs in a shaded situation.

\section{RESULTS}

Table 1 gives the numbers of each major colour phenotype obtained from the crosses where both parents were known and in which substantial numbers of offspring were reared. Table 2 includes data for families where only the female parent was definitely known. Segregation ratios are shown in fig. 1 for the most complete single pedigree. The data are not consistent with single-locus inheritance. The Punnett Square in fig. 2 illustrates a two-locus system which can account for the breeding results. The model involves two unlinked loci with recessive epistasis; each locus having a pair of alleles. Tables 1 and 2 show that the segregation ratios in all families are consistent with this model. One locus $(R)$ can be considered to control red or orange ground colour and the other $(Y)$, yellow. However, gene interaction is involved since moths are red or orange only when one or more dominant $Y$ alleles are present. The two crosses of double heterozygotes which are included in the pedigree of fig. 1 yielded segregations consistent with the expected $9: 3: 4$ ratio of Red:Orange: Yellow moths (table 1). In all cases given in tables 1 and 2 the data when pooled for different types of cross remain consistent with the two-locus model. This is the simplest model consistent with the data.

Table 3 shows that some families reared from wild-caught females yielded small numbers of offspring which do not fit the model. However, dissection of ten other females collected in the wild 
Table 1 Details of families of Callimorpha quadripunctaria for which the colour of both parents was scored. The family from which each parent came is given in parentheses when it is known. Numbers of offspring together with the expected segregation ratio are given. Observed and expected segregations are compared by chi-square (all values are non-significant, $P>0 \cdot 1$ )

\begin{tabular}{|c|c|c|c|c|c|c|c|}
\hline \multirow[b]{2}{*}{ Family } & \multicolumn{2}{|l|}{ Parents } & \multicolumn{3}{|c|}{ Offspring } & \multirow{2}{*}{$\begin{array}{l}\text { Expected } \\
\text { R:Or:Y }\end{array}$} & \multirow[b]{2}{*}{ Chi-square } \\
\hline & Female & Male & Red & Orange & Yellow & & \\
\hline $\mathrm{J} / 87$ & $\mathrm{R}(\mathrm{J} / 86)$ & $\mathrm{R}(\mathrm{J} / 86)$ & 27 & 0 & 0 & $1: 0: 0$ & 一 \\
\hline $12 / 88$ & $\mathrm{R}(\mathrm{J} / 87)$ & $\mathrm{R}(\mathrm{J} / 87)$ & 27 & 0 & 0 & $1: 0: 0$ & - \\
\hline $28 / 88$ & $\mathrm{Y}(7 / 87)$ & $\mathrm{R}(\mathrm{J} / 87)$ & 36 & 0 & 0 & $1: 0: 0$ & - \\
\hline $25 / 88$ & $\mathrm{Y}(4 / 87)$ & $\mathrm{R}(\mathrm{J} / 87)$ & 16 & 0 & 0 & $1: 0: 0$ & - \\
\hline $26 / 88$ & $\operatorname{Or}(4 / 87)$ & $\mathrm{R}(\mathrm{J} / 87)$ & 19 & 0 & 0 & $1: 0: 0$ & - \\
\hline $1 / 85$ & $\operatorname{Or}(\mathrm{M} / 84)$ & $\mathrm{Or}$ & 0 & 39 & 0 & $0: 1: 0$ & - \\
\hline $7 / 85$ & $\mathrm{Y}(\mathrm{R} / 84)$ & $\mathrm{Y}(\mathrm{R} / 84)$ & 0 & 0 & 11 & $0: 0: 1$ & - \\
\hline $4 / 86$ & $\mathrm{Y}$ & $\mathrm{Y}$ & 0 & 0 & $29+$ & $0: 0: 1$ & - \\
\hline $2 / 88$ & $\mathrm{Y}(4 / 87)$ & $\mathrm{Y}(4 / 87)$ & 0 & 0 & 51 & $0: 0: 1$ & - \\
\hline $15 / 84$ & $\mathrm{Y}$ & $\operatorname{Or}(3 / 83)$ & 7 & 0 & 0 & $1: 0: 0$ & - \\
\hline $6 / 85$ & $\mathrm{Y}(\mathrm{P} / 84)$ & $\mathrm{R}(\mathrm{P} / 84)$ & 10 & 0 & 5 & $1: 0: 1$ & $1 \cdot 67$ \\
\hline $7 / 87$ & $\mathrm{Y}(2 / 86)$ & $\operatorname{Or}(2 / 86)$ & 0 & 60 & 62 & $0: 1: 1$ & 0.03 \\
\hline $3 / 86$ & $\operatorname{Or}(8 / 85)$ & $\operatorname{OR}(8 / 85)$ & 0 & 24 & 5 & $0: 3: 1$ & 0.93 \\
\hline $3 / 87$ & $\operatorname{Or}(2 / 86)$ & $\operatorname{Or}(2 / 86)$ & 0 & 21 & 5 & $0: 3: 1$ & 0.46 \\
\hline $1 / 87$ & $\operatorname{Or}(2 / 86)$ & $\operatorname{Or}(2 / 86)$ & 0 & 16 & 6 & $0: 3: 1$ & 0.06 \\
\hline $1 / 88$ & $\operatorname{Or}(7 / 87)$ & $\operatorname{Or}(7 / 87)$ & 0 & 13 & 2 & $0: 3: 1$ & 1.09 \\
\hline $11 / 88$ & $\operatorname{Or}(7 / 87)$ & $\operatorname{Or}(7 / 87)$ & 0 & 6 & 1 & $0: 3: 1$ & 0.43 \\
\hline $16 / 84$ & $R(30 / 83)$ & $\operatorname{Or}(30 / 83)$ & 8 & 9 & 0 & $1: 1: 0$ & 0.06 \\
\hline $2 / 85$ & $\operatorname{Or}(0 / 84)$ & $\mathrm{R}(0 / 84)$ & 28 & 28 & 0 & $1: 1: 0$ & 0.00 \\
\hline $25 / 84$ & $\operatorname{Or}(3 / 83)$ & $\mathrm{R}(30 / 83)$ & 14 & 9 & 0 & $1: 1: 0$ & 1.09 \\
\hline $26 / 84$ & $\operatorname{Or}(25 / 83)$ & $\mathrm{R}(25 / 83)$ & 13 & 21 & 9 & $3: 3: 2$ & $2 \cdot 36$ \\
\hline $5 / 85$ & $\operatorname{Or}(\mathrm{P} / 84)$ & $\mathrm{R}(\mathrm{P} / 84)$ & 7 & 10 & 10 & $3: 3: 2$ & $2 \cdot 53$ \\
\hline $11 / 87$ & $\operatorname{Or}(2 / 86)$ & $\mathrm{R}(2 / 86)$ & 9 & 11 & 7 & $3: 3: 2$ & 0.21 \\
\hline $10 / 87$ & $\operatorname{Or}(2 / 86)$ & $R(2 / 86)$ & 2 & 1 & 3 & $3: 3: 2$ & - \\
\hline $12 / 85$ & $\mathrm{Y}(\mathrm{P} / 84)$ & $\mathrm{R}(\mathrm{P} / 84)$ & 18 & 13 & 35 & $1: 1: 2$ & $1 \cdot 00$ \\
\hline $2 / 86$ & $\mathrm{Y}$ & R & 34 & 30 & 50 & $1: 1: 2$ & $2 \cdot 00$ \\
\hline $4 / 87$ & $\operatorname{Or}(2 / 86)$ & $Y(2 / 86)$ & 24 & 18 & 30 & $1: 1: 2$ & $3 \cdot 00$ \\
\hline $27 / 88$ & $\mathrm{Y}(4 / 87)$ & $\mathrm{R}(4 / 87)$ & 9 & 3 & 11 & $3: 1: 4$ & 0.04 \\
\hline $18 / 88$ & $\mathrm{R}(4 / 87)$ & $\mathrm{R}(4 / 87)$ & 28 & 16 & 12 & $9: 3: 4$ & $3 \cdot 56$ \\
\hline $19 / 88$ & $\mathrm{R}(4 / 87)$ & $\mathrm{R}(4 / 87)$ & 25 & 8 & 14 & $9: 3: 4$ & 0.58 \\
\hline
\end{tabular}

showed that one had one spermatophore, four had two, three had three and two had four. Although Walker (1966) on finding multiple spermatophores in some females taken on Rhodes suggested that these cases resulted from single copulations, thirteen females mated by T.G.L. in captivity showed only a single spermatophore in each individual. Furthermore, in one case a pairing which was left together in a sleeve repaired on the following night. Thus the problematical offspring indicated in table 3 probably resulted from multiple mating and incomplete sperm precedence. The relatively low proportion of such offspring suggests that sperm from the most recent mating fertilize most of the subsequent eggs. Brakefield and Liebert (1985) showed that there is no protandry in a population in south Devon, further suggesting that females tend to pair several times. One important source of loss in our bred material was the failure of up to about one-third of eggs to hatch in some families. It is possible that this occurred because females were only allowed to pair once.

\section{Allele frequencies}

Brakefield and Liebert (1985) give frequency data for the three major colour phenotypes from populations throughout the distribution of the species in Britain. The moth is only found in sheltered areas around a series of estuaries and river valleys in south Devon. Moths were collected in 1983 and 1984. Data for individual populations were homogeneous between years. The frequency data for the 1984 samples pooled for each of five regions are illustrated in fig. 3(A).

The data for all moths scored by us in 1983 and 1984 can be used to infer allele frequencies at the $R$ and $Y$ loci. The calculations assume that the populations are in Hardy-Weinberg proportions and that allelic frequencies at the $R$ locus 
Table 2 Details of families of Callimorpha quadripunctaria for which only the colour of the female parent was known. The source of the female parent is given. The expected segregation ratios are compared with those observed by chi-square (all values are non-significant, $P>0 \cdot 1$ )

\begin{tabular}{|c|c|c|c|c|c|c|c|}
\hline \multirow[b]{2}{*}{ Family } & \multicolumn{2}{|c|}{ Female parent } & \multicolumn{3}{|c|}{ Offspring colour } & \multirow{2}{*}{$\begin{array}{l}\text { Expected ratio } \\
\text { R:Or:Y }\end{array}$} & \multirow[b]{2}{*}{ Chi-square } \\
\hline & Colour & Source & Red & Orange & Yellow & & \\
\hline $7 / 83$ & $\mathbf{R}$ & Starcross & 15 & 0 & 0 & $1: 0: 0$ & - \\
\hline $15 / 83$ & $\mathrm{R}$ & Dawlish & 11 & 0 & 0 & $1: 0: 0$ & - \\
\hline $16 / 83$ & $\mathbf{R}$ & Starcross & 46 & 0 & 0 & $1: 0: 0$ & - \\
\hline $\mathrm{J} / 86$ & $\mathbf{R}$ & Exminster & $25+$ & 0 & 0 & $1: 0: 0$ & - \\
\hline $\mathrm{D} / 86$ & $\mathrm{R}$ & Exminster & $40+$ & 0 & 0 & $1: 0: 0$ & - \\
\hline $\mathrm{I} / 86$ & $\mathbf{R}$ & Exminster & 15 & 0 & 0 & $1: 0: 0$ & - \\
\hline $13 / 85$ & Or & Exeter & 0 & 20 & 0 & $0: 1: 0$ & - \\
\hline $\mathrm{M} / 84$ & Or & Exminster & 0 & 15 & 0 & $0: 1: 0$ & - \\
\hline $10 / 83$ & $\mathbf{R}$ & Dawlish & 17 & 0 & 5 & $3: 0: 1$ & 0.06 \\
\hline $11 / 83$ & $\mathbf{R}$ & Beer & 12 & 0 & 2 & $3: 0: 1$ & 0.86 \\
\hline $8 / 83$ & $\mathbf{R}$ & Starcross & 12 & 12 & 0 & $1: 1: 0$ & 0.00 \\
\hline $21 / 83$ & $\mathbf{R}$ & Starcross & 14 & 14 & 0 & $1: 1: 0$ & 0.00 \\
\hline $14 / 85$ & $\mathrm{R}$ & Exeter & 28 & 25 & 0 & $1: 1: 0$ & $0 \cdot 17$ \\
\hline $3 / 83$ & Or & Otterton & 40 & 56 & 0 & $1: 1: 0$ & $2 \cdot 67$ \\
\hline $20 / 83$ & Or & Teignmouth & 15 & 16 & 0 & $1: 1: 0$ & 0.03 \\
\hline $27 / 83$ & Or & Starcross & 19 & 19 & 0 & $1: 1: 0$ & 0.00 \\
\hline $8 / 85$ & Or & Bradnich & 0 & 21 & 5 & $0: 3: 1$ & 0.46 \\
\hline $25 / 83$ & Or & Dawlish & 3 & 3 & 4 & $(1: 1: 2)$ & - \\
\hline $1 / 83$ & $\mathrm{Y}$ & Dawlish & 11 & 16 & 27 & $1: 1: 2$ & 0.93 \\
\hline
\end{tabular}

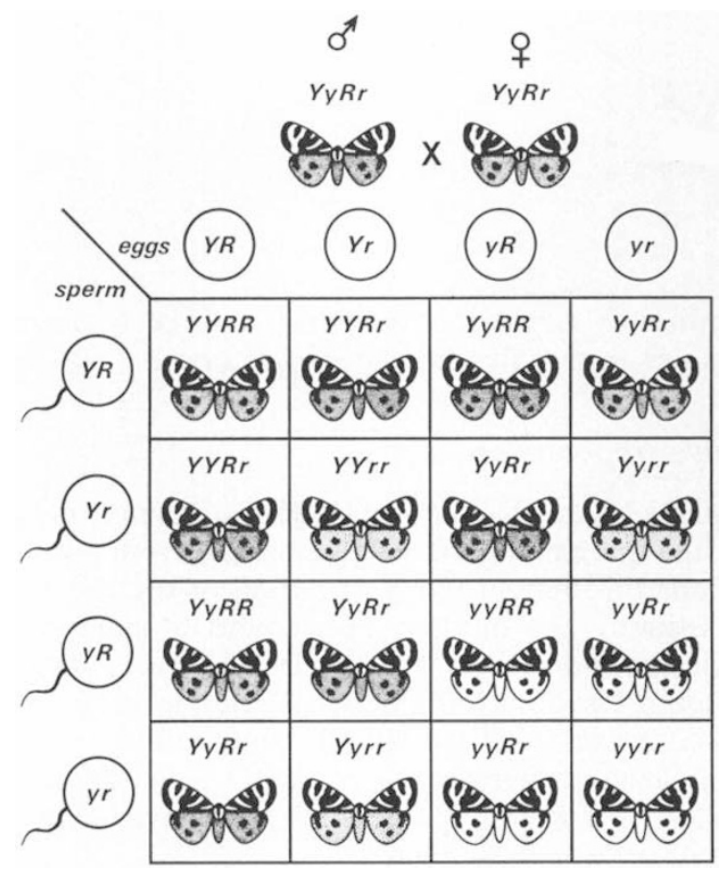

Figure 2 Punnett square illustrating the model for the inheritance of the polymorphism for hindwing colour in Callimorpha quadripunctaria; yellow moths are shown unshaded, orange moths lightly stippled and red moths heavily stippled. are the same for moths of the $y y$ and the $Y y$ plus $Y Y$ genotype classes. The frequency of the recessive $y$ allele is then estimated by taking the square root of the proportion of yellow moths $(y y)$ whilst that of the $r$ allele is estimated as the square root of the proportion of red plus orange moths which are orange $(r r)$. The values are shown in fig. 3(B) and $(\mathrm{C})$.

\section{DISCUSSION}

The dihybrid, recessive epistasis mode of inheritance for the three major colour phenotypes of $C$. quadripunctaria is analogous to that in other cases (Strickberger, 1986; Farnsworth, 1988) including colour polymorphism in the isopod Porcellionides virgatus (Johnson, 1984). Two genes might be involved in regulation of sequential steps in pigment synthesis in $C$. quadripunctaria; the $Y$ locus controlling metabolism of the basic yellow pigment to an intermediate orange one with the $R$ locus controlling subsequent metabolism to red. Our observations suggest that the continuous variability in colour within each of the three major phenotypes is influenced by both polygenes and environmental factors (perhaps including the presence of pathogens). Ford (1955) speculated quite 


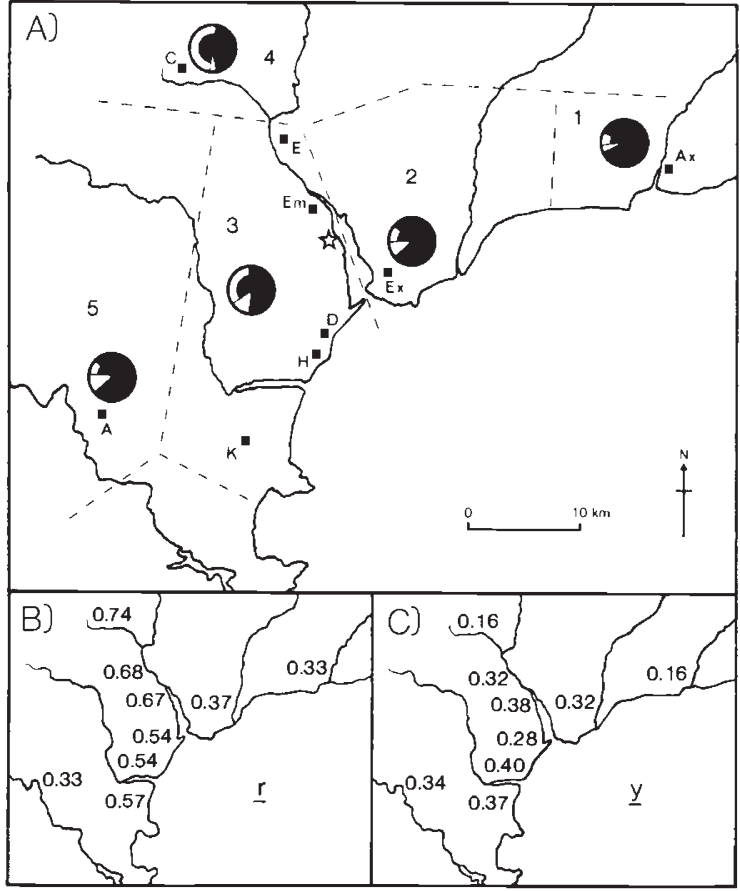

Figure 3 (A) Frequency of the main colour classes of $\mathrm{Cal}$ limorpha quadripunctaria in south Devon in 1984 (data from Brakefield and Liebert, 1985). Pie diagrams show red (in black), orange (halved) and yellow (white) for the pooled samples of moths from each of five regions ( 1 to 5). The star indicates the probable area of introduction. Squares show sites from which larger samples were obtained: Ax, Axmouth; Ex, Exmouth; C, Crediton; E, Exeter; Em, Exminster; D, Dawlish; H, Holcombe; K, Kingskerswell; A, Ashburton. (B) and (C) show the estimates for the frequencies of the $r$ and $y$ alleles, respectively, for the total samples from the individual sites obtained in 1983 and 1984 (sample sizes ranged from 36 to 396 ).

accurately about the genetics of the variation. His studies of the red pigment of Arctiid moths also showed that it can be converted to bright yellow by an acid and restored to red by an alkali (Ford,
1937). Yellow colour forms are widespread in species normally exhibiting this red pigment. Some subspecies of the scarlet tiger moth Panaxia dominula have yellow hindwings (Kettlewell, 1942, 1973). The yellow-coloured race persona found in Italy intergrades in Lombardy with the normal dominula. Genetic differentiation here extends to many other characters and the difference in hindwing colour is controlled by a single locus with heterozygotes intermediate in colour. A study of the area of transition between the polymorphic populations of $C$. quadripunctaria in Brittany and those to the south and east which are monomorphic (see Brakefield and Liebert, 1985) to determine how allele frequencies at the colour loci change and the extent of genetic differentiation at other loci would be of interest.

The region to the west of the Exe estuary is the British stronghold of the Jersey Tiger Moth (region 3 in fig. 3(A)) and is where the species was first recorded in Britain in 1871 probably fairly soon after its introduction. Populations in this region have a rather uniform morph frequency with 50-65 per cent red, $20-40$ per cent orange and 10-20 per cent yellow. Red moths have their highest frequency to the east and west, and orange to the north (Brakefield and Liebert, 1985). This pattern is also reflected in the estimated allele frequencies (fig. 3). The $r$ allele increases in frequency northwards (inland) from the mouth of the Exe and decreases to the east and west. The $y$ allele appears to be somewhat rarer in the extreme north and east of the distribution. Both the gene loci show a high or moderate level of heterozygosity throughout south Devon. The polymorphism may result from a combination of relaxed stabilizing selection on aposematic colour pattern because of reduced diurnal moth activity and climatic selection influencing allele frequencies via non-visual differences in fitness in these ecologically marginal populations.

Table 3 Families reared from wild-collected females which are not consistent with the model. An asterisk indicates offspring which do not fit the model

\begin{tabular}{rllllll}
\hline & & \multicolumn{5}{c}{ Offspring } \\
\cline { 5 - 6 } Family & Female parent & Source & Red & Orange & Yellow & \multirow{2}{*}{ Total } \\
\hline $9 / 83$ & $\mathrm{R}$ & Starcross & 37 & $3^{*}$ & 0 & 40 \\
$2 / 83$ & $\mathrm{R}$ & Beer & 23 & $2^{*}$ & 0 & 25 \\
$30 / 83$ & $\mathrm{R}$ & Teignmouth & 41 & 27 & $4^{*}$ & 72 \\
$18 / 85$ & $\mathrm{R}$ & no data & 38 & $4^{*}$ & $3^{*}$ & 45 \\
$2 / 83$ & Or & Otterton & 19 & 23 & $1^{*}$ & 43 \\
$4 / 85$ & Or & Crediton & $1^{*}$ & 12 & 4 & 17 \\
$16 / 85$ & Or & Crediton & $3^{*}$ & 20 & $2^{*}$ & 25 \\
\hline
\end{tabular}


Acknowledgements We thank an anonymous referee for helpful comments.

\section{REFERENCES}

BRAKEFIELD, P. M. AND LiEBERT, T. G. 1985. Studies of colour polymorphism in some marginal populations of the aposematic Jersey tiger moth Callimorpha quadripunctaria. Biol. J. Linn. Soc., 26, 225-241.

FARNSWORTH, M. W. 1988. Genetics, 2nd edn. Harper \& Row, New York.

FORD, E. B. 1937. Problems of heredity in the Lepidoptera. Biol. Rev., 12, 461-503.
FORD, E. B. 1955. Moths. Collins, London.

JOHNSON, C. 1984. Color-morph genetics in the terrestrial isopods Armadillidium nasatum and Porcellionides virgatus. Can. J. Genet. Cytol., 26, 167-173.

KeTtLeWell, H. B. D. 1942. A survey of the insect Panaxia (Callimorpha) dominula L. Proc. S. Lond. ent. nat. Hist. Soc., 1942-3, 1-49.

KetTlewell, H. B. D. 1973. The Evolution of Melanism. Clarendon Press, Oxford.

STRICKBERGER, M. 1986. Genetics, 3rd edn. Macmillan, New York.

WALKER, M. F. 1966. Some observations on the behaviour and life-history of the Jersey tiger moth, Euplagia quadripunctaria Poda (Lep.: Arctiidae), in the "Valley of the Butterflies", Rhodes. The Entomologist, 99, 1-24. 